\title{
Transformation of Social Security Administrative Body (BPJS) within Social Security Reform in Indonesia
}

\author{
Siti Kunarti ${ }^{1 *}$, Tedi Sudrajat ${ }^{2}$ and Sri Wahyu Handayani ${ }^{3}$ \\ ${ }^{1}$ Faculty of Law, Jenderal Soedirman University, Purwokerto, Central Java, Indonesia \\ ${ }^{2}$ Faculty of Law, Jenderal Soedirman University, Purwokerto, Central Java, Indonesia \\ ${ }^{3}$ Faculty of Law, Jenderal Soedirman University, Purwokerto, Central Java, Indonesia
}

\begin{abstract}
Within the framework of sovereign country under the Constitution of 1945 , the regulation concerning social security stated in Article $28 \mathrm{H}$ paragraph (3) and article 34 paragraph (2). Social security is also guaranteed under the Declaration of Human Rights Year1948 and confirmed in ILO Convention number 102 in 1952 that urge all countries to give maximum protection to labors. As continuation of those regulations, a national system of social security has been formed to result integrated and vast social protection. Transformation of labor security from JAMSOSTEK (Social Protection for Labors), ASKES (Health Insurance) to a mergence called BPJS (Social Security Administrative Body) has been a reforming step that gives legal implication to the rights and responsibility of its stakeholders. The policy of social security system, then demanded that the body is divided into two main different tasks: Health Security Administrative Body (BPJS Kesehatan), Labor Security Administrative Body (BPJS Ketenagakerjaan). This distinction leads to the conversion of membership, programs, asset, liability, workers, right, responsibilities, as well as the addition of a new program called pension security, especially within the framework of Labor Security Administrative Body. This is, in short, to pursue an integrated and inclusive administration of social security.
\end{abstract}

\section{Introduction and literature Review}

Social Security is a program knowledgeable and exercised in almost all nations of the world. Each country has its own social security programs adjusted to the condition it encounters, such as financial, demographical, political and social. Most countries of the world have developed systems and programs of social security which are formally part of their responsibility for the prosperity of their people.

The administration of social security nowadays is a policy generally exercised by all countries despite their ideologies. Not only liberal and neo-liberal countries such as the United States and Europeans countries have developed social security systems, but also

* Corresponding Author: siti_kunarti@yahoo.co.id 
communist countries such as China, Vietnam, and North Korea have dealt with the social security system. This shows that the existence of social security is fundamental, for both the perseverance of a country, and the prosperity of its people.[1] Social security is an essential right that must be fulfilled by a country as part of its constitutional responsibility. It is prescribed in the Universal Declaration of Human Rights proclaimed by the United Nations back in December 10, 1948.

In Indonesia, contextually, the recognition of constitutional right of social security for its people is prescribed in the Constitution of 1945, fourth amendment, Article $28 \mathrm{H}$ which says that each citizen has right of social security. The constitution shows that the administration of social security is assigned to the government, according to Article 34 point (1)-(2). Additionally, the Decree of People's Consultative Assembly No. X/MPR/2001 appoints the president of Republic of Indonesia to form a national system of social security in order to give integrated and inclusive social security to the people.

Social security is a form of social protection system. Vladimir Rys [2] states that social protection is normally understood as an integrated intervention by many parties to protect individuals, families, or communities from various risks of everyday life that are potential to occur, or to overcome the impacts of economic shift, and to support fragile groups of the society.

A formal system of social protection can be grouped into some forms, which are (i) social assistance, (ii) provident fund, (iii) social assurance, (iv) employer's liability (Kertonegoro, 1982).[3] Workers have right of economic, technical and social protection. Social protection [4], is achieved in the form of Labor and Health Social (BPJS Kesehatan and BPJS Ketenagakerjaan).

The policy of social security system is to transform its former administrative bodies that were JAMSOSTEK and ASKES into newly administrative bodies called Health Security Administrative Body (BPJS Kesehatan) and Labor Security Administrative Body (BPJS Ketenagakerjaan). The transformation of such administrative bodies will be continued with the conversion of membership, programs, asset and liabilities, workers as well as right and responsibilities. The regulation of BPJS governs all terms of dismissal and transfer of PT ASKES (Persero) and PT JAMSOSTEK (Persero). Normal dismissal or BUMN Persero is not applicable for the case of PT ASKES (Persero) and PT JAMSOSTEK (Persero), since their dismissal is not followed with liquidation, and Government Regulation is not required. However, Regulation of BPJS does not clearly prescribed whether this term of dismissal and transfer is also valid for other companies like PT ASABRI (Persero) and PT TASPEN (Persero).[5]

\section{Objective of the study}

The questions of the research are as follows:

"How is the social security in Indonesia regulated?"

"How is the transformation process of PT JAMSOSTEK to Health and Labor Security Administrative Body (BPJS Kesehatan dan Ketenagakerjaan)?"

"What are the legal implications of such transformation?"

\section{Methodology}

To describe the transformational process of BPJS, this research employs Normative Judicial and Legal approach, which constitutes the study of primary and secondary legal materials. 


\section{Discussion}

\subsection{Administration of Social Security}

Administering social security is a responsibility of the government in order to protect society's economic and social interest. In the theory of social security as stated by George Rejda [6] there is no longer a dichotomy of central and local government in dealing with the social security administration because a social security is determinant in achieving a unified nation and people's prosperity. In Indonesian context, government plays important role as supervisor, regulator, facilitator as well as contributor. In compliance with the state's financial strength, Indonesia as many other countries has developed social security program based on the funded social security, whose membership is still limited on working society of formal sectors.

A national system of social security is practiced in order to redistribute risks within national scale according to the principles prescribed by the Regulation of the National System of Social Security (SJSN). SJSN is a lifetime security to protect the entire society (upper, middle and lower class) so it is binding and charging the responsibility of workers, employers, and government.[7] Thus, BPJS is an independent organization supported by the constitution to achieve effective administration of national system of social security. And, like its former companies (JAMSOSTEK, ASKES, TASPEN, ASABRI) BPJS is managing trust fund.

As the administrator of social security, BPJS must implement the principle of obligatory participation and cooperation, such as prescribed by Article 5 of the National System of Social Security Act. Obligatory participation is nationally effective and it becomes a characteristic of social security/assurance management. In this case, one or several bodies of BPJS are needed to achieve pooling of risk. In order to achieve effective administration and to fulfil the solidarity principle of social security, one or several administrative bodies with the supporting health facilities are needed in all states, though in terms of social security as public good, there is no dichotomy between federal and local government. In the case of Republic of Indonesia, it is also inacceptable to dichotomize central and local government in administering social security. Both are central holder of responsibility in the administration of social security in the country.

The regulation of social security is started with the issuance of Act no. 40 year 2004 about National System of Social Security (SJSN). On execution, BPJS is established based on the Act no. 24 year 2011 concerning BPJS. It is a public legal organization.

The establishment of Labor Security Administrative Body (BPJS Ketenagakerjaan) on January 12014 as a transformation from PT. JAMSOSTEK (Persero) becomes a real effort of the government to achieve social prosperity. The establishment is based on the Act of National System of Social Security No. 40 year 2004 and the Act of Social Security Administrative Body (BPJS) No. 24 year 2011. Per July 1 2015, Labor Security Administrative Body is fully operated to manage social security for labors with Old Age Security (JHT), Work Accident Security (JKK), Pension Security (JP) and Death Security $(\mathrm{JKm})$. Social security for workers is a facility to achieve social welfare by giving an opportunity to workers/labors who have played important role in the development of the State. [8]

One example of fundamental results of the PT. JAMSOSTEK (Persero) transformation to Labor BPJS is the scale of membership and service orientation. In this case, membership includes all workers of formal sector. The activation of national system of social security has changed the administrative system of labor security and insurance. The administration is now handled by Labor Security Administrative Body (BPJS Ketenagakerjaan) from its former companies (PT. ASKES, PT. TASPEN, PT. ASABRI, PT. JASARAHARJA and PT. JAMSOSTEK). On the other hand, the membership of Labor 
Security is open to all workers, compared to Healthcare security's membership which is open to all citizens of the country. Healthcare security itself is a legal body established to administer healthcare programs. This includes healthcare protection so that the members gain benefits of health security given to those who pay insurance by themselves or supported by the government.[9]

Furthermore, the membership of Labor Security is regulated by the Government Regulation of Roadmap of Labor Security Administration 2013-2019, No. 10 year 2015. After the transformation in January 12014 , the term of LHK workers is classified as nonwage labor (BPU). Programs that can be attended by members from BPU category include Death Security, Work Accident Security, and Old Age Security. This is prescribed in President's Regulation of Staging of Membership of Social Security Program, No. 109 year 2013. LHK workers as categorized into non-wage workers (BPU) mainly focus on informal economy with the following characteristics: micro-scale economy with relatively small capital, low technology, low quality of goods/services, non-permanent location of business, high mobility of workers, uncertain business continuation, irregular working hours, and uncertain amount of income.

\subsection{Transformation of PT. JAMSOSTEK to Labor and Healthcare Security Administrative Body}

There are three stage of how four State-owned companies, PT. ASKES, PT. TASPEN, PT. ASABRI, PT. JASARAHARJA and PT. JAMSOSTEK are transformed under BPJS Act. The highest stage is the straightforward transformational process. BPJS Act straightforwardly transformed PT JAMSOSTEK (Persero) into Healthcare Security Administrative Body, dismissing it while nullifying Act No. 3 year 1992 on JAMSOSTEK. The second stage is not straight forward. BPJS Act does not explicitly transform PT. ASKES into Healthcare Security Administrative Body ever since, it is operated per January 1, 2014. The transformation is an implicit consequence of the term 'dismissal' of the company. The third stage is not transformational. BPJS Act does not state either dismissal or transformation against PT. ASABRI and PT. TASPEN. It only transfers the programs and functions of both companies as pension payer to Labor Security Administrative Body (BPJS Ketenagakerjaan) by 2029 as the latest. How shall both companies continue to be operated is dependent on Government's Regulation as mandated by Article 66 of BPJS Act.

Other than those categories of transformation, BPJS Act prescribes two criteria of transformation. It gives PT. ASKES and PT. JAMSOSTEK two year interval since its issuance on November 25, 2011 to transform and merge themselves into a legal administrative body of social security. In practice, it took one and a half year interval between the operation of Healthcare Security Administrative Body and Labor Care Security Administrative Body.

1. The first criterion is a simultaneous transformation. In this criteria, at the time of the issuance of the Act, per January 1, 2014, PT. ASKES (Persero) was transformed into Healthcare Security Administrative Body (BPJS Kesehatan) and soon operated after the transformation, referring to SJSN Act.

2. The second criterion is a gradual transformation. PT. JAMSOSTEK (Persero) gradually transforms and operates as Labor Security Administrative Body (BPJS Ketenagakerjaan) while still continuing its three undergoing programs: JKK, JKM, and JHT. Labor Security Administrative Body is given one and a half years to complete those programs plus additional Pension Security (JP) in compliance with SJSN Act. By July 1 2015, Labor Security Administrative Body has completed Working Accident Security, Death Security, Old Age Security, and Pension Security programs. 
The division of Social Security Administering Body into two main focuses (health care and labor care) is to achieve an efficient management of social care for the whole citizens. As for Labor Care Administrative Body, it works on additional program of Pension Security by the end of 2029. In conclusion, Labor Care Administrative Body (BPJS Ketenagakerjaan) is a transformational body of not only PT. JAMSOSTEK (Persero), but also PT. TASPEN (Persero) and PT. ASABRI (Persero).

\subsection{Implications of the Transformation}

The establishment of Labor Security Administrative Body (BPJS) per January 12014 leads to the following implications:

1. Conversion of healthcare security programs from JAMSOSTEK to Healthcare Security Administrative Body (BPJS Kesehatan)

2. Transfer of asset and liability, rights and responsibilities of healthcare administration and management of PT. JAMSOSTEK (Persero) to Healthcare Security

3. Preparation of the operation of Labor Security Administrative Body (BPJS Ketenagakerjaan) which includes the development of system and procedure of administering Working Accident Security, Old Age Security, Pension Security, and Death Security and the socialization of the programs to the community

4. Transfer of asset, liability, workers, rights and duties of PT. JAMSOSTEK (Persero) to Health Security Administrative Body (BPJS Ketenagakerjaan)

In its development, according to the management report of Labor Security Administrative Body in 2015, membership of workers from non-wage category (BPU) is still lower (13,14\%) than the target two years earlier in $2013(131,56 \%)$. On the other hand, membership is achieved by $76.72 \%$ in 2014.[10] The data show that BPJS is still struggling to achieve the membership target. The minimum information of Labor Security for BPU becomes general factor of the problem of membership in branch offices. Information is hard to require due to minimum data collection of the vast variety of BPU workers.

In conclusion, it is learned that the transformational process of PT. JAMSOSTEK (Persero) to Labor Security Administrative Body (BPJS Ketenagakerjaan) is not as smooth as planned.

\section{Conclusion}

1. The establishment of Labor Security Administrative Body (BPJS Ketenagakerjaan) per January 12014 as a transformation from PT. JAMSOSTEK is a real effort of the government to achieve social security as mandated by the Act no. 40 year 2004 on National System of Social Security (SJSN) and Act no. 24 year 2011 on Social Security Administrative Body (BPJS). Per July 1 2015, Healthcare Security Administrative Body (BPJS Kesehatan) and Labor Security Administrative Body (BPJS Ketenagakerjaan) is fully operated to manage Social Security. Labor Security includes Old Age security (JHT), Working Accident Security (JKK), Pension Security (JP), and Death Security $(\mathrm{JKm})$.

2. The division of BPJS into health care and labor fields is to achieve efficient management and administration of social security for the society. Labor Security Administrative Body (BPJS Ketenagakerjaan) launched additional program of Pension Security along with the Old Age Security program. This shows that Labor Security Administrative Body (BPJS Ketenagakerjaan) is a transformational body of not only PT. JAMSOSTEK (Persero) but also PT. TASPEN (Persero) and PT. ASABRI (Persero).

3. The transformation per January 12014 leads to some implications: 
a. Conversion of healthcare security programs from JAMSOSTEK to Healthcare Security Administrative Body (BPJS Kesehatan)

b. Transfer of asset and liability, rights and responsibilities of healthcare administration and management of PT. JAMSOSTEK (Persero) to Healthcare Security.

c. Preparation of the operation of Labor Security Administrative Body (BPJS Ketenagakerjaan) which includes the development of system and procedure of administering Working Accident Security, Old Age Security, Pension Security, and Death Security and the socialization of the programs to the community.

d. Transfer of asset, liability, workers, rights, and duties of PT. JAMSOSTEK (Persero) to Health Security Administrative Body (BPJS Ketenagakerjaan).

\section{References}

1. R. S. Badikenita, JI BPJS KTN , 2:1, 1-50 (2017).

2. V. Rys, Merumuskan Ulang Jaminan Sosial: Kembali ke Prinsip-prinsip Dasar, (Pustaka Alvabet, Jakarta, 2011)

3. S. Kertonegoro, Jaminan Sosial, Prinsip dan pelaksanaanya di Indonesia, (Penerbit Mutiara, Jakarta, 1982)

4. Z. Asyhadie, Hukum Kerja, (Raja Grafindo Persada, Jakarta, 2007)

5. W. Rolos, A. Tucunan, dan B. Lampus, Implementasi Program Badan Penyelenggara Jaminan Sosial (BPJS) Kesehatan Di Kabupaten Minahasa Tenggara, (Faculty of Health University of Manado, Manado, 2014)

6. K. L. Henebry, JORI, 62: 4, 797-799 (Des, 1995)

7. H. P. Rajagukguk, Peran Serta Pekerja dalam Pengelolaan Perusahaan (CoDetermination), (Yayasan Obor Indonesia, Jakarta, 2002)

8. A. Khakim, Dasar-Dasar Hukum Ketenagakerjaan Indonesia, (PT Citra Aditya Bakti, Bandung, 2014)

9. I. Widiastuti, Pelayanan BadanPenyelenggaraan Jaminan Sosial, (BPJS) Kesehatan Di Jawa Barat, JURWIDYA, 4:1, 224-233 (2017)

10. B. Arianto, JI BPJS KTN, 2:1, 51-90 (2017) 